\title{
On money as an institution and medium of exchange
}

\author{
Iulia Andreea Bucur Ph.D, \\ Ştefan Sâmbotin Ph.D, \\ "Vasile Alecsandri" University of Bacău, Romania
}

\begin{abstract}
In this working paper we attempted to analysis on money combining the economic and the institutional dimension, on the grounds that we cannot refer to money, in the context of analyzing the human society, strictly from a perspective or another, separately. The subject of our paper implies the concept of "money" approach from two perspectives: institutional and functional, so that thematic area concerns the socio-economic sphere and especially the financial-monetary one.
\end{abstract}

\section{Keywords}

money, institution, medium of exchange, direct exchange, indirect exchange

JEL Code: $E 40$

\section{Introduction}

Part of the financial system, money has an undeniable role in the organization and functioning of economic processes and mutually conditioning the existence and the development, along with other system components: financial instruments, financial markets, financial institutions and central banks ${ }^{1}$. The evolution of economies from predominantly natural form, based on barter, exchange economy, competition has driven a major changes to the role performed by money in all aspects of human and economic activity.

The monetary phenomenon and, in particular, the concept of money have been a constant concern of many prominent economists such as: D. Ricardo, A. Smith, J.R. Malthus, J.B. Say, J.S. Mill, L. Walras, V. Pareto, I. Fischer, C. Menger, F. Bohm-Bawerk, A. Marchall, K. Marx, J.M. Keynes, P. Samuelson, J.K. Galbraith, M. Friedman, L.von Mises, F. von Hayek. In attempts to provide comprehensive explanations of the monetary phenomenon and to define the complex concept of money, the Romanian economists V. Jinga, C. Kiriţescu and others works' also stands, dedicating extensive chapters for the analysis of the money and its role in the economy, based on the monetary practice generalizations from that historical stage.

In the literature and also in current speech there are used both the notion of currency and of money. The term currency, used mostly in the language of French people (monnaie), English people (money), Italian people (moneta), means, according to Larousse dictionary, "a piece of metal issued by sovereign authority, to serve as a medium of exchange". Etymologically, the term money comes from the name of the goddess Junona Moneta, wife of Jupiter, in whose temple at Rome were made the money pieces that celebrated victory over the King of Epirus (Greece). Other nations such as the Romanian one (bani) or German one (geld), use in their language the term with a similar meaning as that attributed to the concept of currency,

\footnotetext{
${ }^{1}$ Cecchetti C.S. (2006), Money, Banking, and Financial Markets, Publisher: McGraw Hill Irwin, New York, p.2
} 
and according to the Explanatory Dictionary of Romanian Language money is "generally equivalent to the value of goods (as a commodity itself); metal or paper currency recognized as a medium of exchange and payment". Etymologically, the Romanian term bani provenance is unknown.

Although for a long time the spheres of the two concepts were not completely overlapping, meaning that the concept of currency was something more comprehensive than money in current conditions, the latter expression has been extended in current speech meaning any instrument of trade, including those that do not have a material existence (scriptural currency or currency of account, electronic currency).

\section{Money as a medium of exchange}

Most people do not spend much wondering What is money?, the main concern regarding the amount of currency held and ways to enhance it. The absence of a clear comprehensive and lasting universally accepted definition of money can be a result of its evolution of forms and functions. Analysis of the money functions is the subject of the differences and even controversies among theorists in time. However, there is a general appreciation that the money meets the following basic functions: medium of exchange, unit of measure, of evaluation and backup tool.

While the first two functions mentioned above are preferred in classical analysis, Keynes's analysis considers that the third one explains many economic phenomena. But, these functions are simple corollary of the main function, that of the medium of exchange.

We, as human beings exist and live together for more than two million years. Currency in its modern forms began to be used by more than three thousand years ago, requiring a long period of time to find that good, in physical shape, which best serves the purpose of medium of exchange.

The idea of money as a medium of exchange could stay together, in terms of importance it holds for society, next to the language (referring to writing and speaking) that constitutes the great intellectual discovery in history. Without language, the exchange of ideas, regardless of their complexity, it would be impossible. Without money, production and exchange of any goods or services would be impossible. Neither difficult nor time consuming of ineffective, but simply impossible!

In explaining the role of money in the economy it is necessary to achieve a trip time and also ask ourselves: Why do people engage in reciprocal exchange? The exchange is the foundation of economic life, without which we can speak of a true economy and human society. The mutual exchange is an agreement between two parties to transfer goods or services of one of them for the other's good and/or services. Thus, both parties enjoy the advantages because each gives a higher value of the asset it acquires by exchange than the renounced one. From Aristotel to Marx, people wrongly thought that exchange somehow involves an equal value. In reality, the exchange was made only because each participant appreciates the two products in a different order.

Why is exchange so spread? Ultimately, due to the great diversity of nature: the human beings and location of natural resources diversity. Every person has a different range of qualities and skills and each natural resource has unique and outstanding characteristics. Specialization allows everyone to develop the best of his abilities and enables each region to highlight its own resources. If no one could be a part of exchange and everyone would be required to independently produce all goods, it is obvious that most of the people would not survive and would live under the poverty line. So, the exchange is vital not only for the economy, but for civilization itself, over time, wearing two forms: direct exchange (barter) and indirect exchange.

The first mentioned form consists in the exchange of goods or services with other goods or services. The two drawbacks are its indivisibility and lack of coincidence of needs. Even when goods are divisible it is generally impossible for the two participants in the exchange to 
enter into relationship with each other and also exchange items are not always accepted by both parties. In the absence of a mediator of exchange we cannot speak of a transaction.

By trial and error, people discovered the path that allows reaching a much larger economy based on indirect exchange. This form require each participant to act instead to sell their product not a commodity which should satisfy a direct need, but another good that can be sold, in turn, for the desired object. Although, at first sight, this gives the impression of an awkward and roundabout operation, it is, in fact, that wonderful tool that makes possible the development of human civilization.

The subject matter of the indirect exchange theory is, therefore, the research relation between the means of exchange involving and the goods and services of all types. The existence of indirect exchange involving one party has a mediator always accepted, not for what he stands for, but its usefulness, represented by money.

History can tell us where and when there were used for the first time means of trade and how then subsequently increasingly reduced the range of goods used for this purpose. Many goods were used as means of exchange: sugar in West Indies, salt in Abyssinia, cattle in ancient Greece, tobacco in colonial Virginia, nails in Scotland, copper in ancient Egypt, grains, pearls, tea, animal skins and pole hooks. Over time, gold and silver have reached the stage of money in the frame of free competition on market, removing the other goods from the role of medium of exchange. Since the distinction between the wider concept of a medium of exchange and restricted concept of the currency is not clear, but the gradual nature, we cannot reach any consensus on the historical transition from simple means of making money exchange.

On a free market, cumulative development from a commodity of a medium of exchange is the only way money could arise. We cannot imagine any other way to generate the money, which can be created only by dynamic processes of a free market.

Indirect exchange and money exist because the necessary conditions for their existence, namely to facilitate the transactions and individuals' awareness of the benefits, has been and continues to be present in human society.

An essential truth about money is clear from the above, that the money is a commodity. It is not an abstract calculation unit, separated by a concrete good, is not a simply symbol with no value, useful only in trade, there is no debt to society and no guarantee for a stable price level. Money is simply a commodity. The only amendment that, unlike other commodities, is required primarily as a medium of exchange. As all goods money assume an existing stock, it faced with requests from individuals to buy and to hold, and "price" is determined by the interaction of total money supply (or stock) with total demand of people to buy and to hold.

In an exchange economy, money in the different forms (coins, paper currency, currency or scriptural account, electronic money), is the only instrument used in the transactions, the only means used to acquire goods and services, while serving to regulate the exchange.

Money has always adapted to the requirements of economic life, being, above all, the intermediate exchange process two distinct transactions: the sale and purchase, separated in time and space just because of its existence.

Core of the exchange system, money, through its use in transactions, determined that the most complex economic exchanges to become more accessible and efficient, while allowing their amplification. It completed exchanges so that buyers and sellers do not claim each other subsequent claims. This is the main role of the money.

\section{The institutional dimension of money}

Affirming that money is the exchange mediator, we refer to the fact that it characterizes a particular exchange system specific to the monetary economies. When talking about money is wrong to understand this concept only in the economic aspect, since money implies an institutional dimension, being inextricably linked to the market. 
Analyzing the money from an institutional perspective, we established as a starting point the presentation of some certain aspects of the concept of institution and attempting to define it first. In J. Knight's view, the institution is a "set of rules that structure social interactions in particular ways. For a set of rules to be an institution the awareness of these rules must be shared by the relevant part of the community or society ${ }^{2}$. In a more explicit way, D.C. North considers institution "a set of rules, procedures and understanding of ethical behavior and ethical norms designed to constrain the behavior of individuals in order to maximize wealth or utility principles"3. As a result, the institution, manifested both as formal organization as well as social order and informal organization reflecting human psychology, culture, traditions, customs and habits of individuals of society means that set of rules generating in social policy. But, for a set of rules to form an institution is necessary that these rules are shared and accepted by a majority of society members. So, the institution sets the rules, in other words, it represents all the constraints created by individuals to shape human interaction. Thus, institutions have the capacity constraint and regulation of behavior in society actors, it is a complex process that involves the development of a series of explicit tasks, such as establishing work rules, monitoring and sanctions.

According to North opinion, institutional framework has a major role in economic performance, the presence of transaction costs required by the existence of constraints to trade. In the absence of such constraints as a result of selfish behavior of individuals, the complex process of exchange could take place much more difficult ${ }^{4}$.

The economist C. Menger, founder of the Austrian school of economics, providing an undeniable theory on the origin of money, and also sought interpretation of the existence of social and economic institutions, especially the development of analysis that only focuses on how certain institutions was specifically designed for well-established. Attempted to discover the cause-effect relations to explain the emergence, change and development of fundamental institutions over time, Menger is a pioneer in providing theoretical support for the concept of social evolutionary processes. Economists consider economic phenomena as results of the interaction of thoughts and actions of countless individuals, human society and the emergence of institutions as an unintended consequence of individual choices pursuing personal interests. Menger's theory on the money illustrates in a forceful manner, its fundamental role which it attributed to the principle of methodological individualism.

Money regarded as an institution is an abstract notion and comprising on the one hand, formal organizations, such as banking institutions (central banks or by issuing commercial banks), treasury and stock exchanges, and, on the other hand, subjective experience individuals that leads them to achieve personal satisfaction and status that is both intense and persuasive that economists talk about a "money illusion".

Being a social-economic tool, indispensable for any economy, money is an historic institution, followed and follows the evolution of human society. The rise or decline of nations have often been deeply marked by the ways to manage money, acted as a factor or development or as an obstacle to development, favoring or hindering, its impact on human communities mirrored into two faces: the obverse and reverse. Money is a universal key that opens everything. It has made possible the division of labor. And perhaps most important achievement is that it enormously raised the potential for exemplary among people. People exchange ideas and valuing their ideas using the language with money.

In terms of institutional, money is underlying the hierarchical differences between individuals of society, human civilization dividing socio-economic classes. This distinction existing since antiquity that characterized the current society has a strong social stratification, so we talk about three great social classes which are distinguished from each other by strong

\footnotetext{
${ }^{2}$ Knight J. (1992), Institutions and social conflict, Cambridge University Press, Cambridge

${ }^{3}$ North D.C. (1981), Structure and Change in Economic History, Norton Company, New York

${ }^{4}$ North D.C. (1990), Institutions, Institutional Change and Economic Performance, Cambridge University Press, Cambridge
} 
features: lower class (workers, unemployed, etc.), middle class which included most of the population and the upper class, whose weight is the lowest in society. The latter is also called the ruling class, power or elite class, as individuals are social actors who are holding power and influence in society: political elites, economic, etc.. The main reason that contributed to widening the gap between social classes over time is the emergence of money. Given the social reality we all live, a phrase that we face almost daily in our society says that "money is power". The philosopher, economist and journalist Karl Marx, author of the famous fundamental work "Capital" (1867) considers that money has the power to buy anything, offering full power. Hence, the fetishism that confuses wealth with money, mercantilist idea that has left deep scars up nowadays and commonly found in phrases like "money power", "rule of money", "sovereignty dollar". In the nineteenth century, English novelist Jane Austen presented the money in his novel "Pride and Prejudice" (1813) as being at the base exemplary and conflicts between individuals. Those belonging to high social class have important tools in fighting life: economic power, financial independence, social impact, capacity of belief, building a very extensive social networks and influence, all having as the foundation holding the most important tool: money.

However, economic elites are not only about this feature, but they become social elites, political authority exercising functions in society, the basic factor is money. Thus, these individuals build and run the company automatically members of society oriented behaviors. This is where the Marxist theory is centered on the idea that dominant elites imposing norms and rules of conduct and develop laws that reflect their interests at the expense of the ruling class whose action is diminished opportunity. It follows therefore the strong institutional character of the social-political side, based on individuals' confidence has proposed a system and a guarantee. In terms of institutional the power of money is based on authority, which has an economic nature, the ability to maintain monetary discipline, financial, tax and also an expanded social and political influence on the strength and stability through government country's military strength and stability, relations with other states and the ability to implement the system of legal rules in the nation.

Vital importance and power of money are showed in any social life spheres. For example, money has a significant impact on the level of education and socio-professional status of society depends on the ability of individuals to pursue certain studies that will influence his career. There are also negative effects on the development side of life in normal society consisting of a series of deviant behavior, antisocial, much of which is determined by lack of money. A negative social significance of the money is also included in corruption. Therefore, we can see that today, money is not only fulfills the function of mediator exchange of goods and services, but this feature has been extended, the currency can be used to "buy" a higher social status, honor, fairness and trust others. It can also degrade mentality, behavior and structure of enabling human beings to obtain favors by failing society's moral values. However, in addition to negative social aspects, there are undeniable and positive meanings of money and we refer to the acts of social assistance, charity to those in need. Money is not only used for negative purposes or getting rich, but it can also be used for positive purposes, to help others.

\section{Final remarks}

What is money? It is a medium of exchange. Money is not a good that people want to consume, but to use it to facilitate the exchange. What to do with money? Money ensures the success of transaction and is always accepted as intermediate element of the exchange. Why is currency necessary? Money is necessary because people cannot live in peace and prosperity in the absence of exchange. How important is the discovery of money? Just look around us. The emergence of the currency was a great advantage to human society. In the absence of a universal medium of exchange would not have been possible a real specialization, no progress of economy beyond the survival level. 
Analyzing money in terms of economic and institutional dimension, we can set out the idea that the two are complementary and also admit that there would be no institutional significance of money if it had not been first economic significance and its functions and in particular, the medium of exchange function.

\section{Bibliography}

1. Basno C., Dardac N., Floricel C. (2001), Monedă, credit, bănci, Editura Didactică şi Pedagogică, Bucureşti;

2. Cecchetti C.S. (2006), Money, Banking, and Financial Markets, Publisher: McGraw Hill Irwin, New York;

3. Jinga V. (1981), Moneda şi problemele ei contemporane, vol I şi II, Editura Dacia, Cluj-Napoca;

4. Kiriţescu C.C. (1982), Moneda - mică enciclopedie, Editura Ştiinţifică şi Enciclopedică, Bucureşti;

5. Knight J. (1992), Institutions and social conflict, Cambridge University Press, Cambridge;

6. North D.C. (1990), Institutions, Institutional Change and Economic Performance, Cambridge University Press, Cambridge;

7. North D.C. (1981), Structure and Change in Economic History, Norton Company, New York;

8. Turliuc V., Cocriş V. (1997), Monedă şi credit, Editura Ankarom, Iaşi;

9. Papadopoulus G. (2008), On money as an institution, de pe http://papers.ssrn.com

10. http://www.dictionareconomic.ro

11. http://misesromania.org 